\title{
The Influence of Hypnoteaching Method on Students' Reading Motivation and Achievement in Secondary School
}

\author{
Lismalinda \\ Iskandarmuda University, Indonesia \\ e-mail: lismalinda@unida-aceh.ac.id
}

\author{
Moriyanti \\ Iskandarmuda University, Indonesia \\ e-mail:moriyanti@unida-aceh.ac.id
}

\begin{abstract}
:
This pre-experimental research was aimed to examine the influence of hypnoteaching method toward students' reading motivation and achievement. The sample was 40 students with purposive sampling technique. Motivation for Reading Questionnaire (MRQ) and test were the research instruments to gain the data quantitatively. Motivation for Reading Questionnaire (MRQ) adopted from Wigfield and Guthrie (1997) to examine students' reading motivation levels. For reading achievement, pre-test and post-test were distributed to assess the students' reading outcome about Narrative Text before and after applying hypnoteaching method. The results of this research showed that the implementation of hypnoteaching method affected students reading motivation and learning outcome. The mean score of pre motivation for reading Questionnaire (MRQ) was 40.2 indicated poor reader and it raised to be 81.1 showing good reader after the implementation of hypnoteaching method. Furthermore, hypnoteaching method also affects English reading result which the mean of pre-test was 45.30 indicating poor score criterion of English subject, meanwhile, after being taught applying hypnoteaching method, the score inclined to 90.25 which asserted good score criterion of English subject. The value of t test was 14.88 from data of pre-test and post-test, however the value of $t$ table was 1.99. It represented that the alternative hypothesis $\left(H_{1}\right)$ was accepted and revealed that hypnoteaching method can influence students' reading achievement. Finally, it was suggested that English teacher should implement this method in teaching English for secondary school students and can be conducted for further research.
\end{abstract}

Keywords: hypnoteaching, influence, reading achievemen, treading motivation

\section{Introduction}

Reading is one of the significant factors in gaining knowledge but the culture of reading is still alarming in Indonesia. Nations prefer watching TV rather than reading books, including senior high school students. Aksan \& Kisac (2009) declared that reading is an essential of study to help people for obtaining knowledge due to reading activity will compile information, understand, 
plan, implement and expression. Reading help persons in many cases, such as training the balance of thinking, reduce stress, mental simulation, improving memory quality, and helping nations connecting to the others. Nevertheless, societies are still reluctant with reading culture, especially English reading in Secondary School.

One of the problems faced in English reading by middle and upper level students is the lack of interest of the students themselves by reason of being lazy to read. The learning motivation of students is basically influenced by several factors, one of which is the learning strategy factor implemented by educators in the teaching and learning process in the classroom. Monotonous methods can cause students bored and do not have passion in accepting the material delivered by educators in case the goals and results of learning are not achieved optimally. Consequently, the researcher interests on investigating students' reading motivation and learning process implemented by the teacher in the classroom.

Hypnoteaching is one of the new learning methods offered to help students achieve enthusiasm in the teaching and learning process that takes place in the classroom. According to Hakim (2010) hypnosis is a situation where someone receives certain information and encouragement to become a person who is better than before. This hypnoteaching method has been applied by educators who have expertise in these fields to increase students' interest in learning in school. Hypnosis is a way to enter or convey positive information through the subconscious to facilitate students in understanding the material conveyed by the instructor. Related to this idea, the instructor can do hypnosis by giving suggestions and imagination. Hypnotherapists give suggestions to students and let them dissolve in the imagination according to the instructions given. The encouragement given will make students more enthusiastic and able to understand material more easily. Hajar (2011) stated that there are several benefits of using hypnoteaching method in the classroom; well-being interaction between students and teacher, developing students interest and talent, varies learning process, motivating students in studying, active learning process, students being more imaginative, and students being more concentrate.

The research that examines hypnosis has done by Budiman (2016). The result of this research found that there is effect Anchor Techniques of Hypnotherapy toward Adolescent Smoking Behaviour Change. Adolescent has a change to be better in shaping their behaviour. After conducting this technique, 11 juvenile stop smoking from 15 people that treated, two people can reduce the intensity and frequency of smoking, and two others only capable to decrease the intensity of smoking.

The related research also has done by Nugraha \& Sugianto (2017). The result of this study explained that hypnotherapy is one of several non-pharmacology methods that can prevent patients from having low self-esteem and help in improving coping mechanisms, thus, the occurrence of psychological disorders and self-adjustment can be prevented.

In this study, researchers would focus on different perspective. It would investigate the influence of hypnosis on education using hypnoteaching method. The researcher would examine the effect of hypnoteaching towards reading motivation and results of English reading. There are problems that the researchers intended to solve in this research (1) To what extend does the hypnoteaching method affect students reading motivation? (2) To what extend does the hypnoteaching method affect students' reading achievement? 


\section{Literature Review}

\subsection{Reading Motivation}

Reading motivation is an important factor in the reading process such as self-confidence in reading, research on interesting reading, social interaction in reading, independence, or opportunities to independently select reading material (Gambrell, 2011; Guthrie \& Wigfield, 2000). Guthrie and Wigfield (2000) explain that motivation factors in reading can be in the form of reading involvement, beliefs, values and goals of the reading process. Motivation can be a driving force for students. The motivated students will try to be more maximal in learning. They will be enthusiastic in learning to improve their language skills, spend more time by learning languages and even understand subjects in their subconscious.

Guthrie and Wigfield (2000) also suggest that motivation in reading is important because students who are intrinsically competent will be motivated in reading because of their curiosity, involvement, and pleasure in challenges. These qualities can increase the frequency of reading and understanding in English reading.

\subsection{Hypnoteaching Method}

Hypnoteaching comes from the words hypnosis and teaching. Hajar (2011) defines hypnoteaching as a learning method by giving suggestions to students so that they become more creative and active. Students are expected to be able to realize that they have extraordinary potential which has not been maximized in learning process at school. The process of learning using hypnosis is more focused on giving positive advice from the teacher to students and students to themselves. These positive suggestions will be encouraged or instructed by the subconscious mind to optimize students' abilities while in class and to control students at the beginning of learning, so students are ready and motivated in learning.

Noer (2010) concluded that hypnoteaching is a learning method that can be applied verbally and non-verbally, persuasively and suggestively to students, thus, they become active and creative. In this method, there is a process of stimulating from thoughts, messages or good feelings using symbols, words, movements, body language, facial expressions, eye contact, and stimulating the mind, so that hypnotized students become creative and active in learning.

Hypnoteaching is a combination of the conscious mind and the subconscious mind in learning process. In fact, the influence and role of the conscious mind is $15 \%$, while the subconscious mind reaches $85 \%$. Thus, the subconscious mind has a greater influence on character formation; the way students think and act well. The conscious and unconscious mind influences each other in the learning process. The conscious mind functions the filter of information that comes and determines whether the need is stored in the subconscious mind or not. Therefore, the conscious mind can protect our subconscious mind (Jaya, 2010).

Hypnoteaching seeks to reduce brain wave frequencies, hence, students become more relaxed and suggestive in capturing the positive value of a teaching process so as to create conducive conditions in the learning process. Hajar (2011) explained that there are seven steps that can be applied by teachers so that the objectives and learning outcomes can be achieved well.

The procedures in the implementation of Hypnoteaching based on Hakim (2010) are:

1. Relaxation Process 
The several things to consider in the relaxation process are:

a) The classroom atmosphere must support the learning and teaching environment of students in order to make students relax.

b) Teacher's appearance, attitudes, beliefs, values, character and teacher's personality.

c) The teacher uses and selects the opening sentence which can calm students.

2. Focused Mind

The teacher not only hears what students are learning but also uses strategies that regulate the level of the mind from beta to alpha. A person's mind is divided into four categories, namely:

a) Mind Beta $(14-30 \mathrm{~Hz})$, in this circumstance everyone is capable to do activities and think in focus.

b) Mind Alfa (8-13.9 Hz), in this situation someone should be in a relaxation and focus. This situation is considered hypnosis process when someone easily gets information in the absence of other disturbing thoughts.

c) Theta Mind (4-7.9 Hz), in this occurrence a person has a half sleep or often named a meditative situation.

d) Delta Mind (0.1-3.9 Hz), in this circumstance, a person is sleeping soundly or in other words in a state of unconsciousness. Hypnosis in the teaching process occurs in the alpha mind. In this state, the teacher considers learners into hypnosis process. It is hoped that information can easily absorbed into the memory of long-term students without any other thoughts that burden him.

3. Subconscious communication

Hakim (2010) states that there are several things to consider unconscious communication between information providers and recipients of information, namely:

a) In the beginning of teaching and learning process, each teacher needs to tell the outline / topic about what he/she will teach the students.

b) The teacher uses the right way to deliver information and how to say it. Avoid mistakes in communication, such as the language used is not in accordance with the information provider and recipient of information; the subconscious mind can only occur if there is conformity.

c) Conducive conditions are the core of unconscious communication. Therefore, avoid things that can limit the communication process between teachers and students.

\section{Research Methodology}

This research is a quantitative descriptive research. This experimental study aims to describe the effect of hypnoteaching method on the motivation and learning outcomes of reading English in class 2 Senior High School students at Islamic Boarding School Misbahul Ulum Lhokseumawe. Whereas, this research data in a quantitative approach used the form of numbers and researchers analyse the data using statistics (Sugiyono, 2007). The method applied in this study is a pre-experimental method in the field of educational psychology. Ary, et al (2010) said that pre-experimental research used one group as research participants, namely the experimental 
group. This experimental group has the treatment of Hypnoteaching method. There were seven steps used in this research based on Hakim's theory which is mentioned in literature review. This study uses one type of pre-experimental method called One-Group Pre-test Post-test Design. According to Ary, et al (2010), there are three steps in applying the One-Group Pre-test Post-test Design: (1) giving a pre-test to measure the dependent variable, (2) using experimental $\mathrm{X}$ for the subject, and (3) giving a post-test to measure the dependent variable.

\subsection{Population and Sample}

The population in this study were all students of class 2 at Madrasah Aliyah of Islamic Boarding School Misbahul Ulum Lhokseumawe. The population as a group of students have the same characteristics and level in knowledge and experience (Hartas, 2010). In other words, the researchers generalized the findings obtained for the study sample. After the population is determined, the research sample is selected as part or subgroup of the population that the researchers chose by using sampling procedure to get the validity of a study.

In this study, the sampling procedure is purposive sampling by determining the characteristics of population and find individuals who fit to these characteristics (Johnson \& Christensen, 2014). Firstly, researchers did preliminary research that observed the class 2 of Madrasah Aliyah students at Islamic Boarding School Misbahul Ulum Lhokseumawe and interviewed the English teachers informally. Finally, researchers obtained the characteristics of the populations who have lack of reading motivation and reading achievement and then tried to find the students who have these characteristics. Thus, the sample of this study is class $2 \mathrm{C}$ of Madrasah Aliyah students at Islamic Boarding School Misbahul Ulum Lhokseumawe who have low score in English Reading in accordance with the criterion of English reading score in school final exam. It was indicated that those students were categorized as low-achiever students in reading comprehension.

\subsection{Instruments}

In this research, Questionnaire and Test were research instruments to get the data regarding research questions. Firstly, the type of questionnaire conducted in this research, namely: Motivation for Reading Questionnaire (MRQ) adopted from Wigfield and Guthrie (1997). MRQ evaluates the reading motivaton level for students of class 2C Madrasah Aliyah at Islamic Boarding School Misbahul Ulum. Researchers administered Pre- Motivation for Reading Questionnaire (MRQ) and Post- Motivation for Reading Questionnaire (MRQ). There are twenty five questions for each MRQ using four likert scale described as follows:

Table: 1 The Scale of Motivation for Reading Questionnaire (MRQ)

\begin{tabular}{lc}
\hline \multicolumn{1}{c}{ Preference } & Scale \\
\hline A Lot Like Me & 4 \\
A Little Like Me & 3 \\
A Little Different From Me & 2 \\
Very Different From Me & 1 \\
No Answer & 0 \\
\hline
\end{tabular}

Secondly, researchers provided two kinds of test, as follows: pre-test and post-test for 40 students of class 2C Madrasah Aliyah at Islamic Boarding School Misbahul Ulum. Pre-test is aimed to measure how far the students' achievement in reading before giving treatment of hypnoteaching method. The researchers compiled the pre-test and post-test questions from 
reading text. The reading text is adjusted to the 2013 curriculum in English subjects for class $2 \mathrm{C}$ of Madrasah Aliyah students at Islamic Boarding School Misbahul Ulum. The material evaluated in the pre- and post-test questions is narrative text material about fairy tales. The pre-test and post-test questions are in the form of narrative text consist of ten multiple choice questions consisting of five answer choices (a, b, c, d, e). After treatment of hypnoteaching method, the researchers also gave the post test for 40 students to measure the improvement of students' achievement in reading. There were 10 questions of pre and post-test based on Narrative text.

\subsection{Data Analysis Procedures}

Data collection in this research was conducted in five meetings. In this study, data collection during the learning process was carried out with two types of data collection techniques, namely questionnaires and tests. In the questionnaire, the list of questions sent to a number of people for their answers to helps obtaining standard results that can be tabulated and treated statistically (Pathak, 2008). The questionnaire used by researchers is the Motivation for Reading Questionnaire (MRQ). This questionnaire was designed to help researchers analyse reading motivation to students in English reading. Researchers describe students' reading motivation based on the results of the Motivation for Reading Questionnaire (MRQ) before and after the hypnoteaching method applied.

The Motivation for Reading Questionnaire (MRQ) designed in four options, the analysis of questionnaire data, "A Lot Like $\mathrm{Me}=4$, A Little Like $\mathrm{Me}=3$, A Little Different From $\mathrm{Me}=2$, Very Different From $\mathrm{Me}=1$ in positive question and no answer $=0$ ". The researchers classified the result of Questionnaire data using scoring rubric based on three level of reading motivation adopted by Wigfield and Guthrie (1997) used: (76 - 100) indicates good reader of reading motivation level, (51 - 75) indicates average reader of reading motivation level, and (26 - 50) indicates poor reader of reading motivation level.

The pre-test and post-test were analysed and tabulated using the value of correct answer. The result of test was related students' achievement in learning reading. Pre-test and Post-test consist of 10 questions about reading and for each question calculated 10 points. As a result, the highest score is 100 points if they answer correctly. The researchers classified the passing grade for students based on the school English score criterion. The passing score of English score criterion was ranged $70-100$ and calculated the mean score of pre-test and post-test.

Finally, after researchers analysed the pre-test and post test score, $\mathrm{t}$ test was calculated using SPSS to examine the hypotheses. Researchers formulated the alternative hypothesis $\left(\mathrm{H}_{1}\right)$ and null hypothesis (Ho) to answer the second research question tentatively. The alternative hypothesis $\left(\mathrm{H}_{1}\right)$ is hypnoteaching method can influence students' reading achievement, while the null hypothesis (Ho) is the hypnoteaching method cannot influence students' reading achievement.

\section{Findings}

\subsection{RQ 1: To what extent does the hypnoteaching method affect students reading motivation?}

The researchers administered Pre - Motivation for Reading Questionnaire (MRQ) at first meeting of the class and Post - Motivational Reading Questionnaire at last meeting of the class. The reading motivation aspects were analyzed in MRQ into 7 aspects identified by Wigfield and Guthrie (1997). Those aspects include Reading Efficacy, Reading Challenge, Reading Curiosity, 
Reading Involvement, Importance of Reading, Reading Compliance and Integrative Orientation. From those seven aspects of reading motivation propose three reading motivation levels, as follows poor reader, average reader, and good reader. The description of students' reading motivation level visualized as follows:

Table: 2 The Description of Students' Questionnaire Answers

\begin{tabular}{lcc}
\hline $\begin{array}{l}\text { Reading Motivation } \\
\text { Level }\end{array}$ & $\begin{array}{c}\text { Pre- Motivation for Reading } \\
\text { Questionnaire (MRQ) }\end{array}$ & $\begin{array}{c}\text { Post- Motivation for Reading } \\
\text { Questionnaire (MRQ) }\end{array}$ \\
\hline Poor Reader & 33 & 1 \\
Average Reader & 5 & 6 \\
Good Reader & 2 & 34 \\
Mean Score & 40.2 (Poor) & 81.1 (Good) \\
\hline
\end{tabular}

The table 1 above visualized the number of students and the mean of reading motivation level from pre- and post-questionnaire. Firstly, from Pre- Motivation for Reading Questionnaire (MRQ), the result showed that 33 students were poor readers of reading motivation. Moreover, there were 5 students who became the average reader of reading motivation. Besides that, only two students gained good readers of reading motivation. As a result, the mean score of PreMotivation for Reading Questionnaire (MRQ) was 40.2 indicating poor readers. However, the mean score of Post- Motivation for Reading Questionnaire (MRQ) was 81.1 represented good readers. To be specific, there were 34 students who obtained good readers, 6 students of average readers and only a student was poor reader from Post- Motivational Reading.

\subsection{RQ 2: To what extent does the hypnoteaching method affect students' reading achievement?}

After students answered pre-test and post-test about Narrative Text, researchers ranged and compared the students' score from pre-test and post-test. The scores were ranged based on English score criterion in the research location. It was presented in the following table 2:

Table: 3 The Distribution of Students' Reading Score

\begin{tabular}{lccccc}
\hline \multirow{2}{*}{ Score Interval } & \multirow{2}{*}{$\begin{array}{c}\text { Score } \\
\text { Criterion }\end{array}$} & Pre Test & Post Test & Pre Test & Post Test \\
\cline { 3 - 5 } & Not pass & 35 & 2 & $87.5 \%$ & $5 \%$ \\
$70-69$ & Pass & 5 & 38 & $12.5 \%$ & $95 \%$ \\
\hline
\end{tabular}

From table 2 above, it can be seen that students' learning outcomes after being taught with the hypnoteaching method has increased. This can be seen the improvement of percentage that occur at the pass score criterion from $12.5 \%$ to $95 \%$. Meanwhile, there was the decline of percentage at the not pass score criterion from $87.5 \%$ to $5 \%$ after being taught by using the hypnoteaching method.

Moreover, researchers also evaluated $t$ test to determine the influence of hypnoteaching methods on students' reading achievement. The results are presented in the table 3 below: 
Table: 4 T test Results of Data Paired Students' Reading Achievement

\begin{tabular}{|c|c|c|c|c|c|}
\hline Test & Mean & $\begin{array}{l}\text { Standard } \\
\text { Deviation }\end{array}$ & t- Test & $\begin{array}{c}\mathrm{df} \text { (Degree of } \\
\text { Freedom) }\end{array}$ & $\begin{array}{c}\mathrm{t}-\mathrm{table} a \\
0.05\end{array}$ \\
\hline Pre- Test & 45.30 & 15.78 & \multirow[b]{2}{*}{14.88} & \multirow[b]{2}{*}{78} & \multirow[b]{2}{*}{1.99} \\
\hline Post- Test & 90.25 & 10.81 & & & \\
\hline
\end{tabular}

Based on Table 3 above, the mean score of pre-test was 45.30 represented that almost students of class 2C at Madrasah Aliyah of Islamic Boarding School Misbahul had difficulties in reading Narrative Text. After the treatment of hypnoteacing method, almost students achieved 90.25 in post-test. Finally, the result of pre- test and post-test depicted the significant difference and obtained the result of $t$ - test was 14.88 based on df (Degree of Freedom) 78 and $t$-table 1.99.

\section{Discussion}

This research tries to investigate the influence of hypnoteaching method toward reading motivation and achievement in Madrasah Aliyah of Islamic Boarding School Misbahul Ulum Lhokseumawe. It outlined on the findings of the research based on different perspective from the previous research and elaborated from different research instruments. Firstly, the comparison of the result from Pre- Motivation for Reading Questionnaire (MRQ) and PostMotivation for Reading Questionnaire (MRQ) can be summarized that students of class $2 \mathrm{C}$ had an attempt to minimalize the negative statement in their mindset while they were learning English reading through hypnoteaching method, for example the negative statement about $I$ hate English reading passages become positive thinking, for instance, I enjoy the challenge of difficult English passages. Therefore, almost students chose option of A Lot Like Me (4 points) about positive statement on Motivation for Reading Questionnaire (MRQ) that represented their feeling and thought about learning English reading passage.

In addition, the mean score of Motivation for Reading Questionnaire (MRQ) was 40.2 indicating poor reader in reading motivation from pre-questionnaire. After applying hypnoteaching method, the mean score of Motivation for Reading Questionnaire (MRQ) increased to be 81.1 indicating good reader of reading motivation in post-questionnaire. In sum up, almost students of class 2C Madrasah Aliyah at Islamic Boarding School Misbahul Ulum were good reader because they are motivated in reading Narrative text after they get the stimulus from their teacher about the value of learning because hypnoteaching tries to solve the students' problem in negative statement in their mind when they learned English language. It gives positive statement in learning English language. Positive statement is the way of thinking, saying and acting positively. For example, I can do this reading assignment.

Furthermore, the researchers also expresses the emotional words in hypnoteaching process. It is technique to attract all students in the class. The examples of emotional words in the expression that the researchers used the word "desire" and "success" in the sentence "if you have the desire to be the best student, I am sure that you have success now and in the future". It is one of aspects in intrinsic motivation assessed in Motivational Reading Questionnaire (MRQ). It can provoke the students' intrinsic motivation in reading. Reading Curiosity, Reading Involvement, and Reading Challenge classified into an aspect, defined as Intrinsic Value of Reading. 
There are five questions regarding Reading Curiosity aspects in MRQ, as follows: by learning to read in English, I hope I will be able to read English novels (question 1); even if reading were not a required subject, I would take a reading class anyway (question 6); I like reading English novels (question 10); by learning to read in English, I hope to be able to read English newspapers and/or magazines (question 12); and I like reading English newspapers and/or magazines (question 14). Secondly, three questions in MRQ represent Reading Involvement aspect, as follows: I tend to get deeply engaged when I read in English (question 2); It is fun to read in English (question 13); and I get immersed in interesting stories even if they are written in English (question 25). Lastly, Reading Challenge is evaluated in question 20 about I enjoy the challenge of difficult reading passages.

As a result, among those seven reading motivation aspects, 39 students answered A Lot Like Me $=4$ in intrinsic motivation aspects (Reading Curiosity, Reading Involvement, and Reading Challenge) in MRQ in Post- Motivation for Reading Questionnaire (MRQ) for students of class 2C Madrasah Aliyah at Islamic Boarding School Misbahul Ulum. As a result, there were 34 good readers and 6 average readers from students because of intrinsic value in reading. The intrinsic motivation aspects (Reading Curiosity, Reading Involvement, and Reading Challenge) gave positive effect for them to be enthusiastic in reading. It conformed these findings to Mori's research findings (2002) for Kyoto Tachibana Women's University students who obtained high loadings from the intrinsic motivation factors for EFL leaners because the learners tried to think positively about reading English passage as self-hypnosis when they learned reading English. They gave positive responses toward reading English passages. As EFL leaners, they must try to change behavior to be success in the future.

The related research was also examined by Hasbullah \& Rahmawati (2015) that suited to the present findings even though different level of respondents. This research aimed to figure out the effect of implementation of hypnoteaching method on university students' motivation in learning English at mathematics department. The results of Hasbullah and Rahmawati's research concluded that there was an influence of the hypnoteaching method on students' motivation learning English of the UNINDRA PGRI Mathematics Education study program.

Moreover, hypnoteaching also has same effect to hypnotheraphy process. Both of them can reduce and change someone's bad behavior. It was investigated by Budiman (2016) that Anchor Techniques of Hypnotherapy can alter to be better in shaping someone's behavior for adolescent. In present study, hypnoteaching also tries to make students reduce their negative thought and habit toward reading English passage. As a result, they were enthusiastic in reading English passage and feel pleasurable while learning English passages.

Secondly, researchers also obtained the findings from pre- test and post- test presented on Table 3 above. It can be concluded that almost students from Class 2C were enthusiastic in reading Narrative Text when they answered the post test. There were 38 students who passed English score criterion (70-100) with the mean score of post-test 90.25 after applying Hypnoteaching method. As a result, there was a significant improvement of reading score toward students' reading achievement. Besides, researchers also evaluated the value of $t$ test to prove the hyphoteses in this research. The value of $t$ - test was 14.88 from data of pre-test and post-test, while the value of $t$ table was 1.99 at $\mathrm{df}$ (Degree of Freedom) 78 and the significance level $\alpha 0.05$. It was clear that the value of $t$ - test was higher than the value of $t$ table. It can be inferred that the 
null hypothesis (Ho) offered was refused and the alternative hypothesis $\left(\mathrm{H}_{1}\right)$ was accepted and it clearly showed that the hypnoteaching method can influence students' reading achievement.

The present findings corresponded to Hadi Kasmaja's research although different subject matter. Kasmaja (2017) implemented hypnoteaching method in Mathematics for junior high school in Bulukumba. There was an enhancement in Mathematics learning outcomes of students in class VII at SMPN 41 Bulukumba after using the hypnoteaching method with an increase in student learning outcomes.

\section{Conclusion}

It can be concluded that there was the influence of hypnoteaching method toward the students' reading motivation of secondary school. The students were motivated intrinsically while they learned English reading passages. The intrinsic motivation aspects (Reading Curiosity, Reading Involvement, and Reading Challenge) provided the positive effect for students to be passionate in reading. It was benefical for students to be more spirited to gain their success in learning English reading passages specifically.

Apart from this, hypnoteaching method also influence English reading achievement in Narrative text based on the result of pre-test and post-test. Consequently, the alternative hypothesis $\left(\mathrm{H}_{1}\right)$ was approved so that the hypnoteaching method can influence students' reading achievement. It was gainful for teachers to increase students' reading achievement by adopting hypnoteaching as a reference of teaching method to achieve the teaching objectives.

Finally, these present findings examined by researchers about the effect of hypnoteaching for secondary school students in learning English reading passages can be worthwhile for the future research to be brenchmark in elaborating the effect of Hypnoteaching with different limitation in English skills (listening, writing or speaking skills) and different students' level.

\section{Acknowledgements}

Researchers would like to dedicate respect and thanks to the ministry of Research, Technology and Higher Education of the republic Indonesia who has funded for this research. Then, researchers would say thanks to headmaster of Islamic Boarding School Misbahul Ulum Lhokseumawe, teachers, staff, and all beloved students as the participants in this research.

\section{References}

Aksan, N., \& Kisac, B. (2009). A descriptive study: Reading comprehension and cognitive awareness skills. Procedia Social and Behavioral Sciences, 1, 834-837.

Ary, Donald et al. (2010). Introduction to Reseacrh in Education (Eighth Edition). United States of Amerika: Wadsworth.

Budiman. (2016). Efektivitas Hypnoterapi Teknik Anchor Terhadap Perubahan Perilaku Merokok Remaja [The Effectiveness of Anchor Technique Hypnotherapy towards Changes In Youth Smoking Behavior]. PSIKIS: Jurnal Psikologi Islami, Vol 2. No 2, 2016. 135-148.

Gambrell, L. B. (2011). Seven Rules of Engagement: What's Most Important to Know about Motivation to Read. The Reading Teacher, Vol 65. No 3, 2011. 172-178. doi: 10.1002/TRTR.01024. 
Guthrie, J. T., \& Wigfield, A. (2000). Engagement and Motivation in Reading. In M. L. Kamil, P. B. Mosenthal, P. D. Pearson, \& R. Barr, Handbook of Reading Research (pp. 403-422). Mahwah: Erlbaum.

Hajar, I. (2011). Hypnoteaching Memaksimalkan Hasil Proses Belajar-Mengajar dengan Hypnoterapi [Hypnoteaching Maximizes the Results of Teaching and Learning Using Hypnotherapy]. Yogyakarta: Diva Press.

Hakim, A. (2010). Hypnosis in Teaching, Cara Dahsyat Mendidik dan Mengajar [Hypnosis in Teaching, the Powerful Way to Educate and Teach]. Jakarta: Visiamedia.

Hartas, D. (2010). Educational Research and Inquiry. London: Continuum International Publishing Group.

Hasbullah \& Rahmawati. (2015). Pengaruh Penerapan Metode Hypnoteaching Terhadap Motivasi Belajar Mahasiswa Universitas Indraprasta PGRI [The Influence Hypnoteaching Methods on Student Motivation in Indraprasta PGRI University]. FORMATIF: Jurnal Ilmiah Pendidikan MIPA, Vol 5. No. 1, 2015. 83-90.

Jaya, N. T. (2010). Hypno-Teaching (Bukan Sekedar Mengajar) [Hypnoteaching (Extraordinary Teaching)]. Yogyakarta: D-Brain.

Johnson, R. B., \& Christensen, L. (2014). Educational Research: Quantitative, Qualitative and Mixed Approaches. Thousand Oaks: SAGE.

Kasmaja, H. (2017). The Effectiveness of the Implementation of Hypnoteaching Method to Improve Motivation and Mathematics Learning Result of Class VII Students at Smpn 41 Bulukumba. Jurnal Daya Matematis, Vol 5. No. 1, 2017. 103-119.

Mori, S. (2002). Redefining Motivation to Read in a Foreign Language. Reading in a Foreign Language, Vol 14. No. 2, 2002. 91-110.

Noer, M. (2010). Hypnoteaching for Success Learning. Yogyakarta: Pedagogia.

Nugraha \& Sugianto (2017). Hipnoterapi pada Pasien Nyeri Kronik. [Hypnotherapi in Chronic Pain patients]. Berkala Ilmiah Kedokteran Duta Wacana, Vol. 2, No. 2, 2017. 317-324.

Pathak, R. P. (2008). Methodology of Educational Research. New Delhi: Atlantic Publisher \& Distributors.

Sugiyono. (2007). Metodologi Penelitian [Research Methodology]. Bandung: Alfabeta.

Wigfield, A. \& Guthrie J. T. (1997). Relations of children's motivation for reading to the amount and breadth of their reading. Journal of Educational Psychology, Vol. 89, 420-432. 